\title{
FIG4 Gene
}

National Cancer Institute

\section{Source}

National Cancer Institute. FIG4 Gene. NCI Thesaurus. Code C124943.

This gene plays a role in the metabolism of polyphosphoinositides. 